\title{
Motivation to Transfer, Supervisor Support, Proactive Learning, and Training Transfer: Testing Interaction Effects
}

Submitted 21/03/19, $1^{\text {st }}$ revision 13/05/19, $2^{\text {nd }}$ revision 20/06/19 accepted 26/07/19

\author{
Julitta Dewayani ${ }^{1}$, Augusty Ferdinand ${ }^{2}$
}

\begin{abstract}
:
Purpose: This study aims to examine the interaction effect of motivation to transfer supervisor support, and proactive learning on training transfer.

Design/Methodology/Approach: Data is obtained from 213 managers of rural banks in Central Java - Indonesia who had participated in management training programs. Structural equation modeling (SEM) is applied to test the proposed hypothesis.

Findings: The results show that motivation to transfer supervisor support and proactive learning have a significant effect on training transfer.

Practical Implications: The study gives attention to motivation to transfer supervisor support as well as proactive learning to improve training transfer. It is expected that the recommendations made may encourage the success of training transfer.

Originality/Value: This study contributes to the training literature by showing proactive learning to improve training transfer.
\end{abstract}

Keywords: Motivation to transfer, supervisor support, proactive learning, training transfer.

JEL codes: G34.

Paper type: Research article.

\footnotetext{
${ }^{1}$ School of Electronics and Computer (STEKOM), Indonesia, corresponding author: littadew@gmail.com

${ }^{2}$ University of Diponegoro, Faculty of Business and Economics, Indonesia
} 


\section{Introduction}

Training is an important part of the organizational practice to improve and develop employee knowledge, skills, and attitudes. Good training programs can provide relevant learning experiences and increase employees capability to work effectively (Goldstein, 1986). Training programs are designed to create a win-win situation for organizations and employees to complete tasks within the organization. Organizations and employees are able to achieve the goals set if learning expertise can be transferred effectively to be applied in the workplace.

Employees perceive training as a crucial factor for developing their skills and career advancement, while organizations invest a certain amount of money to develop employees to face global competition. However, training is often criticized for investment because it provides low yields and it is less effective. According to the American Society for Training and Development study, organizations in America have spent more than $\$ 125$ billion per year on training and development (Paradise, 2007). At the same time, these organizations continue to ask for concrete results from the training expenses. Burke (1997) states that trainees only use $40 \%$ of what they have learned after the training program is completed. Holton et al. (2000) show that only $10 \%-30 \%$ had been learned in training programs implemented in the workplace, so the organizations lost $70 \%-90 \%$ of investment training. The researchers suggest that the knowledge and expertise gained from training are not fully applied to the work. There is a training problem that is the lack of transfer from what has been learned during training (Ana-Inés et al., 2014).

Training transfer is an important element in the effectiveness of training that helps employees and organizations to improve performance. The main objectives of training activities are the provision of expertise, abilities, and knowledge of employees to achieve organizational goals. Transfer motivation is a driver in the training transfer process. It is difficult to transfer learning effectively without motivation. In other words, to transfer expertise and knowledge that has been learned, trainees should have transfer motivation, because motivation can affect employee willingness to apply what has been learned in the training program. There are only a few transfer motivation studies that affect training transfer (Naquin and Holton, 2002) if compared to studies of motivation to learn about training transfer. Therefore, transfer motivation is still an unexplored subject of study (Noe and Schmitt, 1986)

\section{Literature Review}

\subsection{Proactive Learning}

Knowledge is an important factor to ensure the sustainability of competitive advantage because it is indeed difficult to replicate and becomes the foundation for continued differentiation (Wiklund and Shepherd, 2003). Therefore, organizations 
must develop and implement a series of activities to help disseminate organizational capabilities and values adopted, in other words, organizations must practice knowledge management (Grant, 1996). The main objective of knowledge management practices is to gain awareness of the importance of knowledge, both individually and collectively, and shape knowledge management practices more effectively and efficiently. Learning orientation helps employees to develop an understanding of the work environment, improve knowledge and motivate work intelligently (Sujan et al., 1994).

Senge (1990) notes that organizational learning occurs only through individuals who learn. Individual learning is a prerequisite for organizational learning (Kim, 1993). Nanoka et al. (1992) emphasize that learning at the individual level is the foundation, where knowledge is created by individuals. Learning orientation represents a broad set of activities, namely organizations create and utilize knowledge to gain competitive advantage (Calatone et al., 2002). Commitment to learning, shared vision, openness, and sharing of intra-organizational knowledge are the cornerstones of learning orientation (Calatone et al., 2002; Sinkula et al., 1997; Hurley and Hult, 1998).

Individuals who are able to change the environment can appear more effective performance. It can be illustrated that individuals with a proactive personality are relatively not limited by situational forces and have initiatives to create changes in the environment for gaining organizational benefit (Bateman and Crant, 1993). Proactive individuals will be self-starters, show initiative, take future-oriented actions to change work situations to improve organizational effectiveness (Crant, 2000).

\subsection{Motivation to Transfer}

Motivation to transfer is the direction, persistence, intensity of effort to utilize the expertise and knowledge that has been studied (Seyler et al., 1998; Bates and Holton, 2007). Motivation to transfer is the curiosity of trainees to use the knowledge and expertise obtained from training programs at work (Axtell and Yearta, 1997; Noe and Schmitt, 1986). Learning and motivation are essential for training transfer (Gegenfurtner et al., 2009). Without learning nothing can be transferred and without motivation, nothing can be transferred from learning to work.

Behavior change tends to occur in trainees who succeed in learning and the desire to apply their new knowledge, skills, and abilities in the workplace. The objectives of learning orientation influence proactive behavior. Individuals who have a high learning goal orientation will have the choice to master new aspects (Dweck, 1986) who tend to be more attached to the proactive behavior of seeking feedback (Tuckey et al., 2002). Parker and Collins (2010) investigate how learning orientation predicts proactive behavior in information seeking such as seeking feedback and innovation 
ideas. By obtaining diagnostic information, individuals will evaluate the gap between the current and ideal level of proficiency to provide guidance on how to sharpen knowledge and skills. Thus, the research hypothesis is:

\section{H1: Motivation to transfer is related to proactive learning.}

\subsection{Training Transfer}

Training transfer is the ability of trainees to absorb the knowledge and expertise gained from training and use it in the workplace (Yamnill and McLean, 2001). If the training material is the same as work actualization, the transfer rate can be maximized which in turn improve performance. Training transfer is understood as a change produced by employee behavior caused by training activities that are followed (Segers and Gegenfurtner, 2013). Blume et al. (2010) suggest that training transfer is the consistency of the application of knowledge, skills, and abilities that have been obtained during training in the workplace.

Some studies suggest that learning is a prerequisite for training transfer that takes place in the workplace (Pineda, 2010; Baldwin and Ford, 1988a; Goldstein and Ford, 2002; Thayer and Teachout, 1995). If employees acquire new knowledge, skills, and abilities from training, they will positively apply training results as in several studies conducted in insurance companies (Leach and Liu, 2004), banking (Liebermann and Hoffmann, 2008), hospitality (Tracey et al., 2001), electronic and electrical industry (Xiao, 1996). Proactive employees are able to create and influence their environment to conduct training transfer. Likewise, the opportunity to use the knowledge and expertise obtained from training will affect training transfer. Employees who have proactive behavior are able to identify opportunities that bring positive changes to the work environment (Crant, 2000). Therefore the research hypothesis is:

\section{H2: Proactive learning is related to training transfer.}

\subsection{Supervisor Support}

Supervisor support is supervisor behavior that is able to optimize employees to use the knowledge, expertise, and attitudes obtained from training in the workplace (Nijman et al., 2006). Supervisors support encouraging trainees to use acquired expertise, providing assistance to identify situations where expertise can be used, provide guidance in the application of expertise, and provide feedback which overall facilitates positive training transfer (Leonard Karakowsky, 1999).

The findings of a study conducted by Baldwin and Ford (1988b) concluded that the results of training namely learning and retention was directly influenced by three training inputs: training design, trainee characteristics, and climate transfer. Supervisors have the potential to influence training transfer during the transfer process phase, namely before, during and after training (Machin, 2002). Supervisor 
support is one of the crucial variables that have an impact on training, attention implementation and training transfer (Ford et al., 1992).

Blume et al. (2010) indicate that the supervisor's support has a strong relationship with training transfer. The ability of supervisors to allocate time and encourage employees to take part in training and apply new learning obtained from training in the workplace is able to produce positive training transfer ( $\mathrm{Ng}$ et al., 2011). In other words, the supervisor encourages employees to apply what they have learned from workplace training, which significantly affects the level of employee training transfer. Therefore the research hypotheses are:

H3: Supervisor support is related to proactive learning.

H4: Supervisor support is related to training transfer.

\section{Research Methodology}

The sample of this study is managers of rural banks (Bank Perkreditan Rakyat) in Central Java - Indonesia. Out of 256 questionnaires distributed, 213 were returned and could be analyzed (response rate $=83.2 \%$ ). Socio-demographic respondents were 122 men $(57.3 \%)$ and 91 women $(12.7 \%)$. The average age is $25-35$ years with work experiencxe of fewer than 5 years. The majority of respondents were university graduate $(59.6 \%)$, diploma $(39 \%)$ and others $(0.9 \%)$.

Motivation to transfer is measured by 3 items developed by Noe and Schmitt (1986) and it has been used in a previous study by Martijn et al. (2013). Training transfer is measured by 4 items which adapted from Velada et al. (2007). Supervisor support is measured by 4 items which adapted from Xiao (1996).

Data were analyzed using confirmatory factor analysis with AMOS 22.0 software package. The measurements used in the goodness of fit are $x^{2 /}$ degrees of freedom, the minimum sample discrepancy function (CMIN/DF), goodness-of-fit index (GFI), adjusted goodness of fit index (AGFI), Trucker Lewis Index (TLI), comparative fit index (CFI) and root mean square error approximation. Sobel-test is also used to assess the significance of the mediating variable.

\section{Findings and Discussion}

The results of the goodness of fit indicate that the model meets the fit index criteria: $\chi 2=121.148$ (cut off value $\leq \chi 2=257.76$ ), $\mathrm{df}=99, \mathrm{p}=0.065$ (cut off value $\geq 0.05$ ), $\mathrm{GFI}=0.933$ (cut off value $\geq 0.90$ ), $\mathrm{TLI}=0.979$ (cut off value $\geq 0.90$ ), $\mathrm{AGFI}=0.907$ (cut off value $\geq 0.90$ ), $\mathrm{CFI}=0.983$ (cut off value $\geq 0.90$ ), $\mathrm{RMSEA}=0.032$ (cut off value $\leq 0.08$ ), $\chi 2 / \mathrm{df}=1.224$ (cut off value $\leq 2$ ). Reliability testing is used to test the extent to which instruments can be categorized to be reliable if they provide consistent results. Table 1 presents the composite reliability of all constructs exceeding 0.7 and the factor loading exceeding 0.6. Moreover, the AVE of all 
Motivation to Transfer, Supervisor Support, Proactive Learning, and Training Transfer:

146

constructs exceeding 0.5 . The result of structural model along with the path coefficients and significance values is shown in Table 2.

Table 1. Result of Measurement Model

\begin{tabular}{lccc}
\hline Construct and indicators & Factor loadings & $\begin{array}{c}\text { Composite } \\
\text { reliability }\end{array}$ & $\begin{array}{c}\text { Average } \\
\text { extracted }\end{array}$ \\
\hline Motivation to transfer (MT) & 0.793 & 0.809 & 0.585 \\
MT1 & 0.745 & & \\
MT2 & 0.756 & & \\
MT2 & & 0.825 & 0.543 \\
Proactive learning (PL) & 0.720 & & \\
PL1 & 0.695 & & \\
PL2 & 0.711 & & \\
PL3 & 0.695 & & \\
PL4 & 0.837 & & \\
PL5 & & & \\
Training transfer (TT) & 0.773 & & \\
TT1 & 0.735 & & \\
TT2 & 0.703 & & \\
TT3 & 0.707 & & \\
TT4 & & & \\
Supervisor support (SS) & 0.816 & & \\
SS1 & 0.715 & & \\
SS2 & 0.728 & & \\
SS3 & 0.725 & & \\
SS4 & & & \\
\hline
\end{tabular}

Table 2. Hypotheses Testing

\begin{tabular}{|c|c|c|c|c|c|c|}
\hline \multicolumn{3}{|c|}{ Hypotheses } & \multirow{2}{*}{$\begin{array}{c}\begin{array}{c}\text { Standardized } \\
\text { coefficients }\end{array} \\
0.302\end{array}$} & \multirow{2}{*}{$\frac{\mathrm{t} \text { value }}{3.555}$} & \multirow{2}{*}{$\frac{\rho}{0.000^{*}}$} & \multirow{2}{*}{$\begin{array}{c}\text { Result } \\
\text { Supported }\end{array}$} \\
\hline H1 & $\begin{array}{l}\text { Motivation } \\
\text { transfer } \\
\text { Proactive } \\
\text { Learning }\end{array}$ & $\begin{array}{l}\text { to } \\
\rightarrow\end{array}$ & & & & \\
\hline $\mathrm{H} 2$ & $\begin{array}{l}\text { Proactive } \\
\text { Learning } \\
\text { Training } T_{1}\end{array}$ & $\begin{array}{l}\overrightarrow{ } \\
\text { fer }\end{array}$ & 0.309 & 3.655 & $0.006^{*}$ & Supported \\
\hline H3 & $\begin{array}{l}\text { Supervisor } \\
\text { Support } \\
\text { Proactive } \\
\text { Learning }\end{array}$ & $\rightarrow$ & 0.224 & 2.766 & $0.000 *$ & Supported \\
\hline $\mathrm{H} 4$ & $\begin{array}{l}\text { Supervisor } \\
\text { Support } \\
\text { Training T }\end{array}$ & $\begin{array}{l}\overrightarrow{\text { fer }} \\
\text {. }\end{array}$ & 0.200 & 2.367 & $0.000 *$ & Supported \\
\hline
\end{tabular}

Note: * Significant at $\rho \leq 0.05 ; t \geq 1.96$.

Table 2 shows that all hypotheses proposed in this study are supported. Motivation to transfer is significantly related to proactive learning $(\beta=0.302, p<0.05)$ and $(\mathrm{t}=$ 
$3.555>1.96)$. Sobel test for mediation shows that the mediating effect is significant $(\mathrm{Z}=2.343, p<0.005)$. Proactive learning is significantly related to training transfer $(\beta=0.309, p<0.05)$ and $(\mathrm{t}=3.655>1.196)$. Supervisor support is significantly related to proactive learning $(\beta=0.224, p<0.05)$ and $(\mathrm{t}=2.766>1.96)$. Supervisor support is significantly related to training transfer $(\beta=0.200, p<0.05)$ and $\mathrm{t}=2.367$ $>1.96$.

The results of the study showed that there is a significant positive relationship between motivation to transfer and proactive learning. This finding is consistent with several previous studies (Kenny et al., 2016; Podsakoff et al., 2000). It can be concluded that employees who have the objectives of learning orientation like challenges and are motivated to learn and master new skills. These employees become proactive to manage and responsible for learning and better performance. In other words, goal-oriented employees have a tendency to show proactive behavior by showing their competence to fellow organizational members.

The results of the study showed that proactive learning has a significant effect on training transfer. This relationship confirms the study of Srikanth (2013) that employees with proactive personality are in a better position to training transfer results. This indicates that individuals who are proactive are able to create and influence the environment, which allows conducting training transfer. Liebermann and Hoffmann (2008) suggest that learning has a direct effect on training transfer. Employees feel that they can work better through the utilization of knowledge gained. When more knowledge is learned from training, more behavioral changes can be found in the workplace (Maister, 2008).

The results also found that supervisor support has a significant positive effect on training transfer. This finding supports several previous studies (Facteau et al., 1995; Lim and Johnson, 2002; Khin and Sujinda, 2014). Employees expect a supportive environment where they get supervisor support to apply the knowledge that they have. This shows that positive training transfer is highly dependent on supervisor support at work. The results also found that there is a significant relationship between supervisor support and proactive learning. This confirms the study of Buch et al. (2001) that supervisor support is important to facilitate knowledge among organizational members. Sharing knowledge will not be value to employees or organizations unless they need the knowledge to accept and apply it. For this reason, supervisor support will help employees to become motivated, get encouragement to obtain, disseminate, transfer and apply existing knowledge (Riege, 2005).

\section{Conclusion}

The results of this study emphasize that training as an employee development strategy contributes to improving performance. Motivation to transfer can be increased by providing training materials that are appropriate to employees so that they can add and expand their knowledge and expertise. This will make employees 
become motivated and increase their self-confidence to develop and improve their careers. The organization can also encourage trainees to actively share and brief employees in order to develop their knowledge, abilities, and expertise so that they can improve their competencies.

Further studies can be carried out by including other factors that influence the success of training transfer such as the characteristics of trainees, design training and work environment to be able to strengthen the results of this finding

\section{References:}

Ana-Inés, R.D., José-Miguel, G.J., Manel, G.F. and Ángel-Pío, S.G. 2014. Transfer of learning Motivation, training design and learning conducive work effects. European Journal of Training and Development, 38(8), 728-744.

Axtell, C.M., Maitlis, S. and Yearta, K.S. 1997. Predicting immediate and longer-term transfer of training. Personnel Review, 26(3), 201-213.

Baldwin, T.T. and Ford, K.J. 1988a. Transfer of training: a review and directions for future research. Personnel Psychology, 41, 63-105.

Bateman, T.S. and Crant, M.J. 1993. The proactive component of organizational behavior: A measure and correlates. Journal of Organizational Behavior, 14, 103-118.

Bates, R., Kauffeld, S. and Holton, I.F.E. 2007. Examining the factor structure and predictive ability of the German version of the learning transfer system inventory. Journal of European Industrial Training, 31, 195-211.

Blume, B.D., Ford, K.J., Baldwin, T.T. and Huang, L.J. 2010. Transfer of training: A metaanalytic review. Journal of Management, 36(4), 1065-1105.

Burke, L.A. 1997. Improving Positive Transfer: a Test of Relapse Prevention Training on Transfer Outcomes. Human Resources Development Quartely, 8, 115-128.

Buch, R., Dysvik, A., Kuvaas, B. and Nerstad, L.G.C. 2001. It takes three to tango: Exploring the interpaly among training intensity, job autonomy, and supervisor support in predicting knowledge sharing. Human Resources Management, 54(4), 253-269.

Calatone, R.J., Cavusgil, T. and Zhao, Y. 2002. Learning Orientation, Firm Innovation Capability and Firm Performance. Industrial Marketing Management, 31, 515-524.

Crant, J.M. 2000. Proactive Behavior in Organizations. Journal of Management, 26(3), 435462.

Dweck, C.S. 1986. Motivational Processes Affecting Learning. American Psychologist, 41, 1040-1048.

Facteau, J.D., Dobbins, H.G., Russell, A.E.J., Ladd, T.R. and Kudisch, D.J. 1995. The Influence of General Perceptions of the Training Environment on Pretraining Motivation and Perceived Training Transfer. Journal of Management, 21, 1-25.

Ford, J., Quiñones, M., Sego, D. and Sorra, J. 1992. Factors affecting the opportunity to perform trained skills on the job. Personnel Psychology, 45(3), 511-527.

Gegenfurtner, A., Veermans, K., Festner, D. and Gruber, H. 2009. Motivation to Transfer Training: An Integrative Literature Review. Human Resource Development Review, 8(3), 403-423.

Goldstein, I. and Ford, K.J. 2002. Training in Organizations. 4th ed. Belmont, CA, Wadsworth. 
Goldstein, I.L. 1986. Training in organization: Needs assessment, development, and evaluation (2nd ed.). Pacific Grove, CA, BrooWCole.

Grant, R.M. 1996. Toward A Knowledge-based Theory of the Firm. Strategic Management Journal, 17, 109-122.

Holton, E.F., Bates, R. and Ruona, A.E.W. 2000. Development of a Generalized Learning Transfer System Inventory. Human Resources Development Quartely, 11, 333-360.

Hurley, R.F. and Hult, M.T. 1998. Innovation, market orientation and organizational learning: an integration and empirical examination. Journal of Marketing, 62(3), 4254.

Kenny, W.T.T., Al K.C., Helena D. and Sherry, A.Y.S. 2016. The effect of learning goal orientation and communal goal strivings on newcomer proactive behaviours and learning. Journal of Occupational and Organizational Psychology, 89, 420-445.

Khin, M.M. and Sujinda, C. 2014. The result of the importance of supervisor support and peer support in transfer of training. International Journal of Business, Economics and Law, 4(1), 82-88.

Kim, D.H. 1993. The Link between Individual and Organizational Learning. Sloan, Management Review, 35(1), 37-50.

Leach, M.P. and Liu, H.A. 2004. Investigating interrelationships among sales training evaluation methods. Journal of Personal Selling \& Sales Management, 23(4), 327339.

Leonard Karakowsky, A.R.E. 1999. The role of trainee and environmental factors in transfer of training: an exploratory framework. Leadership \& Organization Development Journal, 20(5), 268-276.

Liebermann, S. and Hoffmann, S. 2008. The impact of practical relevance on training transfer: evidence from a service quality training program for German bank clerks. International Journal of Training and Development, 12(2), 74-86.

Lim, D.H. and Johnson, D.S. 2002. Trainees' Perceptions of Factors that Influence Learning Transfer. International Journal of Training and Development, 6(1), 36-48.

Machin, M.A. 2002. Planning, managing, and optimizing transfer of training. In Kraiger, K. (Ed.), Creating, Implementing, and Managing Effective Training and Development, Jossey-Bass, San Francisco, CA, 263-301.

Maister, D.H. 2008. Why (most) training is useless. Training and Development, 62(5), 53-58.

Martijn, V.D.L., Karen, D.V. and Chiaburu, S.D. 2013. Getting the most of management training: the role of identical elements for training transfer. Personnel Review, 42(4), 422-439.

Nanoka, I., Amikura, H., Kanai, T. and Kawamura, T. 1992. Organizational Knowledge Creation and The Role of Middle Management. Annual Conference of Academy Management.

Naquin, S.S. and Holton, I.F.E. 2002. The effects of personality, affectivity and work commitment on motivation to improve work through learning. Human Resource Development Quartely, 13(4), 357-376.

Ng, K.H., Ahmad, R. and Ismail, A. 2011. The impact of the supervisor's role in training programmes on the transfer of training: A case study in four East Malaysian local governments. Research and Practice in Human Resource Management, 19(2), 2442.

Nijman, D.J.J., Nijhof, J.W., Wognum, M.A.A. and Veldkamp, P.B. 2006. Exploring differential effects of supervisor support on transfer of training. Journal of European Industrial Training, 30(7), 529-549. 
Noe, R.A. and Schmitt, N. 1986. The influence of trainee attitudes on training effectiveness: test of a model. Personnel Psychology, 39, 497-523.

Paradise, A. 2007. State of the Industry: ASTD's Annual Review of Trends in Workplace Learning and Performance. Alexandria, VA, ASTD.

Parker, S.K. and Collins, G.C. 2010. Taking stock: integrating and differentiating multiple proactive behaviors. Journal of Management, 36(3), 633-662.

Pineda, P. 2010. Evaluation of training in organisations: a proposal for an integrated model. Journal of European Industrial Training, 34(7), 673-693.

Podsakoff, P.M., MacKenzie, B.S., Paine, B.J. and Bachrach, G.D. 2000. Organizational Citizenship Behaviors: A Critical Review of the Theoretical and Empirical Literature and Suggestions for Future Research. Journal of Management, 26(3), 513-563.

Riege, A. 2005. Three-dozen Knowledge Sharing Barriers Managers Must Consider. Journal of Knowledge Management, 9(3), 18-25.

Segers, M. and Gegenfurtner, A. 2013. Transfer of training: New conceptualizations through integrated research perspectives. Educational Research Review, 8, 1-4.

Senge, P. 1990. The fifth discipline: The art and practice of learning organization. New York, Currenc/Doubeday.

Seyler, D.L., Holton, F.E., Bates, A.R., Burnett, F.M. and Carvalho, A.M. 1998. Factors Affecting Motivation to Transfer Training. International Journal of Training \& Development, 2(1), 2-16.

Sinkula, J.M., Baker, E.W. and Noordewwier, T. 1997. A Framework for Market Based Organizational Learning: Linking values, Knowledge and Behavior. Journal of the Academy of Marketing Science, 25(4), 305-318.

Srikanth, P. 2013. The Impact of Proactive Personality in Predicting Training Outcomes. Asia Pacific Journal of Business and Management, 4(2), 1-18.

Sujan, H., Weitz, A.B. and Kumar, N. 1994. Learning, orientation, working smart, and effective selling. Journal of Marketing, 58(3), 39-48.

Thayer, P.W. and Teachout, S.M. 1995. A Climate for Transfer Model: AL/HR- TP-1995 0035, Air Force Material Command. Brooks Air Force Base, San Antonio, TX.

Tracey, J., Hinkin, T., Tannenbaum, S. and Mathieu, J. 2001. The influence of individual characteristics and the work environment on varying levels of training outcomes. Journal of Human Resource Development Quarterly, 12(1), 5-23.

Tuckey, M., Brewer, N. and Williamson, P. 2002. The influence of motives and goal orientation on feedback seeking. Journal of Occupational and Organizational Psychology, 75, 195-216.

Velada, R., Caetano, A., Michel, W.J., Lyons, D.B. and Kavanagh, J.M. 2007. The effects of training design, individual characteristics and work environment on transfer of training. International Journal of Training and Development, 11, 282-294.

Wiklund, J. and Shepherd, D. 2003. Knowledge-based resources, entrepreneurial orientation and the performance of small medium-sized business. Strategic Management Journal, 24, 1307-1314.

Xiao, J. 1996. The Relationship Between Organizational Factors and the Transfer of Training in the Electronics Industry in Shenzhen, China. Human Resource Development Quarterly, 1(1), 55-73.

Yamnill, S. and McLean, N.G. 2001. Theories Supporting Transfer of Training. Human Resource Development Quarterly, 12(2), 195-208. 